\title{
Plauto brasileiro: breve história das traduções da comédia plautina no Brasil ${ }^{1}$
}

Renan de Castro Rodriguez e Beethoven Barreto Alvarez*

\section{Introdução: por uma história das traduções de Plauto}

Neste artigo, apresentamos um estudo sobre a historiografia das traduções produzidas ou publicadas no Brasil, desde o século XIX até hoje, 2019, da obra de Tito Mácio Plauto (c. 254-184 a.C.), importante autor de comédias na Roma dos séculos III-II a.C. Este texto pretende investigar o percurso tradutório das comédias de Plauto no Brasil, elucidando neste caminho, de forma ainda que breve, o contexto das traduções e um pouco de seus processos e projetos, contribuindo com uma história da tradução da literatura latina no Brasil.

Segundo Adriane Duarte (2016), a história da tradução dos clássicos greco-latinos no Brasil ainda está por ser escrita, e isso é um fato, mas, embora haja muito para ser feito ainda, sabemos que esse trabalho vem sendo feito.

Recentemente, além do próprio trabalho de Duarte, "Por uma história da tradução dos clássicos greco-latinos no Brasil", publicado na revista Translatio, em 2016, vemos o crescente número de pesquisas que se interessam pela historiografia da tradução da literatura greco-latina em terras brasileiras, como as de Rodrigo Tadeu Gonçalves e Bruno Vieira (2010), que organizaram um

\footnotetext{
${ }^{1}$ Este artigo é uma versão ampliada em co-autoria de um trabalho final do curso "Estudos da tradução: abordagens e pesquisas", ministrado pela professora Gionava Cordeiro, da Pós-Graduação em Estudos da Linguagem, da Universidade Federal Fluminense.

* Universidade Federal Fluminense (UFF).
} 
dossiê intitulado "Tradução dos clássicos em português", publicado na Revista Letras; a de Paulo Sérgio de Vasconcellos (2011), que desenvolveu estudo sobre a tradução poética nos estudos clássicos no Brasil, publicado pelo periódico Scientia traductionis, vinculado à Pós-Graduação em Estudos da Tradução da Universidade Federal de Santa Catarina (UFSC); a de Mauri Furlan (2013), que organizou um dossiê intitulado "Em torno da (re)tradução dos clássicos", também publicado pela Scientia traductionis; e, mais especificamente em torno apenas da literatura latina, os trabalhos de Eduardo Tuffani (2006), que compilou, num livro fundamental para as pesquisas nacionais, um repertório de trabalhos e traduções de língua e literatura latina publicados no Brasil, entre os anos de 1830 e 1996; ${ }^{2}$ e de Thaís Fernandes (2017), que desenvolveu, em sua tese de doutorado, um estudo sobre a história das traduções da literatura latina publicadas no Brasil, entre os anos de 1808 e $2014 .^{3}$

Nessa esteira e a partir desses estudos, pretendemos sistematizar aqui uma história das traduções plautinas já produzidas e publicadas no Brasil, destacando os principais nomes que atuaram nessa produção4. Alguns dados sobre essa história já poderiam ser encontrados em Tuffani (2006) e Fernandes (2017); assim, o que objetivamos realizar aqui é ampliar a coleta dos dados já existente, levando também em consideração as traduções realizadas em trabalhos acadêmicos ${ }^{5}$ (e, portanto, não necessariamente publicadas na forma de livro), bem como discutir, ainda que de forma concisa, algumas questões dos projetos tradutórios particularmente.

Para isso, dividimos esse artigo em três recortes diacrônicos, cada um relativo a um século (XIX, XX e XXI), refletindo três momentos distintos da produção tradutória no Brasil. Esse estudo, embora tenha também um caráter um tanto quantitativo, como os próprios trabalhos de Fernandes

\footnotetext{
2 O trabalho de Tuffani está sendo complementado pelo pesquisador e incorporará também língua e literatura grega. Versão preliminar do repertório grego pode ser encontrada em: <https://etuffani.com.br>.

${ }^{3}$ De forma fragmentária, diversos textos acadêmicos, como teses e dissertações, acabam por fazer em alguma altura uma história da tradução de seus objetos e autores, como em Cairolli (2014), por exemplo. ${ }^{4}$ Por uma questão de tempo e escopo, não trataremos da tradução de Terêncio (185-159 a.C.) nem das traduções, de Plauto ou Terêncio, produzidas ou publicadas em Portugual ou outro país de língua portuguesa, embora seja prentensão estender a pesquisa posteriormente.

${ }^{5}$ Nem Fernandes (2017) nem Tuffani (2006), por exemplo, consideram dissertações e teses.
} 
(2017), Duarte (2016) e Tuffani (2006), pretende ir um pouco além, propondo algumas reflexões sobre o estabelecimento de uma tradição tradutória no Brasil, a partir da análise de algumas discussões dos próprios tradutores de Plauto.

Ao fim, apresentaremos um panorama do que está sendo realizado atualmente em termos de tradução plautina, à guisa de considerações finais.

\section{Traduções plautinas do século XIX}

No século XIX, com a criação, pela família real portuguesa, da imprensa no Brasil, uma nova fase da produção intelectual começa a se estabelecer, o que pode ser rapidamente visto com a aparição de algumas traduções de literatura estrangeira feitas por poetas da época. ${ }^{6}$ Essa imprensa, denominada Imprensa Régia (13/05/1808), teve um papel fundamental no que diz respeito à impressão de livros na colônia e, consequentemente, também em relação à circulação de livros traduzidos de literaturas estrangeiras. É, nesse mesmo período, que surgem as primeiras tipografias, localizadas em Pernambuco, no Rio de Janeiro e na Bahia (REIS, 2015).

A partir disso, ainda nesse período, alguns tradutores de literatura clássica surgiram e consolidaram seus nomes na história da tradução brasileira. Dentre eles, o grande nome, inquestionavelmente, foi o poetatradutor Odorico Mendes (1799-1864), nascido em São Luís do Maranhão. Dentre suas obras, podemos destacar as traduções das duas principais épicas gregas: Ilíada (1874) e Odisseia (1928), além das obras do poeta latino Virgílio: Eneida, Bucólicas e Geórgicas, que foram compiladas na coleção Virgílio Brasileiro (1858). ${ }^{7}$

Além de Odorico, podemos citar outros nomes que auxiliaram nos estudos clássicos da tradução do Brasil, como João Gualberto (1787-1861), Ramiz Galvão (1846-1938) e o próprio Imperador Dom Pedro II (1825-1891)8, que foi um dos grandes nomes da tradução de diversas línguas nesse período. Entretanto, nenhum desses tradutores se debruçou sobre as obras

\footnotetext{
${ }^{6}$ A respeito da história da tradução nos séculos anteriores (XVI ao XVIII), ver Reis e Milton (2016).

7 Para uma discussão mais detalhada sobre a importância de Odorico Mendes, ver Duarte (2016, p. 45 et seq.).

${ }^{8}$ Para saber mais sobre as traduções de D. Pedro II, ver Vieira (2010) e Daros (2012)
} 
de Plauto. Até onde nossa investigação se estendeu, apenas um poeta se ocupou desse papel nesse período: João Cardoso de Meneses e Sousa, o Barão de Paranapiacaba (1827-1915).

O Barão de Paranapiacaba foi um importante poeta, tradutor e jornalista do século XIX. Ao todo, escreveu trinta obras e fez quinze traduções, das quais podemos destacar algumas, feitas em versos portugueses, como Prometeu Acorrentado, de Ésquilo, Nuvens, de Aristófanes, Antígone, de Sófocles, e Aulularia, de Plauto.

A Aulularia, ou A Marmita (1888), na tradução do Barão, é, possivelmente, a primeira e única obra de Plauto traduzida para o português no século XIX, como atesta o próprio testemunho do tradutor: “É, creio, o primeiro ensaio que do teatro latino se faz em verso português. Escasso é o seu mérito literário, mas representa paciente esforço para trasladar em vernáculo os modelos da arte antiga" ${ }^{\prime \prime}$ (p. 4). Nessa obra, como proposta tradutória, o Barão escolheu verter os polimétricos versos latinos para "versos portugueses", respeitando o sistema métrico vernáculo de sua tradição poética. É interessante destacar que a primeira tradução de Plauto tenha se dado em território brasileiro. Sua principal proposta foi recriar um sistema métrico de versos vernáculos que refletisse a polimetria do latim, utilizando três tipos de versos diferentes. Vejamos a seguinte explicação de Flores e Gonçalves (2014) sobre os tipos métricos utilizados pelo tradutor:

\footnotetext{
O Barão de Paranapiacaba (João Cardoso de Meneses e Sousa), em sua tradução da Aulularia intitulada A Marmita, elege três modelos básicos de estrutura rítmica derivados da tradição poética lusófona: dodecassílabos, decassílabos e redondilhas maiores, todos rimados, alternando-se basicamente a cada cena da peça. (p. 152)
}

A alternância entre os três modos métricos, digamos assim, entre o uso dos dodecassílabos (à época, alexandrinos clássicos), dos decassílabos (preferencialmente heroico, mas também o sáfico) e das redondilhas maiores, parece respeitar uma motivação conscenciosa. A maioria das cenas e, normalmente, aquelas em que o personagem Euclião aparece tendem a ser

\footnotetext{
${ }^{9}$ Citamos essa e outras passagens com a ortografia modernizada.
} 
vertidas em redondilhas (sem nenhuma preocupação com alguma isomorfia ou proporção definida em termos de números de versos); sem essa preocupação numérica também, decassílabos são escalados para diálogos ou monólogos mais longos, independentemente do conteúdo; e restam os alexandrinos para algumas cenas em que atuam escravos e, principalmente, para o prólogo ${ }^{10}$. Decassílabos e alexandrinos sempre com rimas emparelhadas, e redondilhas com alternadas.

Em relação à sua prática tradutória, o Barão de Paranapiacaba ressalta humilde, no seu prefácio, como manda o decoro, que sua tradução possui erros e defeitos, sendo inferior ao texto original, no qual está presente a "pureza da língua" utilizada pelos grandes nomes da literatura latina:

\footnotetext{
Dou testemunho do meu, colocando sob o amparo do nome ilustre e consagrado de V. Ex., esta minha versão da Aulularia, de Plauto. [...] Escasso é o seu mérito literário; mas representa paciente esforço para trasladar em vernáculo os modelos da arte antiga, fonte, em que se vai retemperar o gosto e restaurar a pureza da lingua.

V. Ex., cuja elegância e elevação de estilo prova sérios estudos clássicos, constituindo-o Juiz Competente, relevará os erros e defeitos, que nesse trabalho encontrará e a minha ousadia em oferecer-lhe tão peco fruto de tosco e humilde engenho. (1888, p. 12)
}

Porém, pelo contrário, a tradução do Barão é engenhosa e elegante; varia em estilo: é agil e ajeitada nas redondilhas; sóbria nos decassílabos e bem despojada nos alexandrinos. Une a tradição métrica da comédia clássica quinhentista, que se valia dos decassílabos e redondilhas, à então recente prática da tradução do drama cômico em alexandrinos ${ }^{11}$, inaugurada por António F. de Castilho, que traduzira, de Molière, Tartufo (1870) e O Avarento (1871).

\footnotetext{
${ }^{10}$ No século XIX, havia uma tradição, no teatro cômico brasileiro, de versos alexandrinos com rimas emparelhadas. Dentre alguns dramaturgos que utilizavam esse verso, podemos destacar Machado de Assis, que escreveu três peças com esse tipo de verso: Deuses de casaca (1866), Antes da missa (1878) e Bote de rapé (1878). Para um estudo mais aprofundado sobre essas peças, ver Amparo (2008).

${ }^{11}$ Sobre a utilização dos alexandrinos na tradução dramática, ver Alvarez (2019, p. 116).
} 
É importante destacar, por fim, o pioneirismo do poeta ao traduzir um autor que não estava no centro das escolhas tradutórias da época ${ }^{12}$. Entretanto, pelo prefácio que nosso Barão escreve, fica claro que foi exatamente o sucesso recente do Avarento, de Molière, fosse em francês ou na tradução de Castilho, que motivou a escolha da Aulularia. Sua justificativa inicial parece desvelar essa correlação: “A Aulalaria ou Marmita devia merecer a atenção da crítica, ainda quando não tivesse outro mérito senão o de haver inspirado o Avarento de Molière." (1888, p. 7).

O Barão deseja se vincular a uma tradição ainda mais antiga e para isso relembra: "A Aulularia é das peças de Plauto que se conservou por mais tempo no repertório da idade média. Dela fez uma espécie de parodia o autor do Querolus (Chorão). Vital de Blois, poeta latino do século XII, [...]." (1888, p. 9).

E, como veremos nas próximas seções, a Aulularia continuará ganhando outras tantas traduções, mantendo-se, seja por suas traduções ou por suas imitações, sempre no centro do sistema literário. ${ }^{13}$

\section{Traduções plautinas do século $X X$}

Depois do século XIX, o século XX apresenta um crescimento de traduções da literatura greco-latina, tendo por destaque grandes nomes como Carlos Alberto Nunes (1897-1990), Péricles Eugênio da Silva Ramos (1919-1992) e Mario da Gama Kury (1922). Esse período é denominado por Adriane Duarte como "era dos diletantes", uma vez que muitos dos tradutores do período eram amantes das artes e da literatura, e não se dedicavam a elas como um ofício principal em suas vidas (DUARTE, 2016, p. 50). Nossa investigação demonstra que nenhum desses poetas, tradutores, ou poeta-tradutores, traduziu obras de Plauto, tendo sido dada maior

\footnotetext{
12 A título de informação, os outros autores da literatura latina que estavam no centro das escolhas tradutórios desse período eram Virgílio, que teve diversas traduções das suas três obras, Eneida (18451846, 1858); Bucólicas (Éclogas), (1846, 1858, 1866, 1883-1888) e Geórgicas (1858); e Horácio, que também teve muitas traduções de suas obras, como a Arte Poética $(1883,1887)$, as Odes $(1851,1894)$ e as Sátiras (1834). Para conferir um repertório mais completo sobre as traduções da literatura latina, ver Tuffani (2006) e Fernandes (2017).

${ }^{13}$ Lembramos a famosa imitação de Ariano Suassuna, O Santo e a Porca, de 1957; e vale dizer que uma adaptação da peça com fins educacionais encontra-se como material didático no livro Aprendendo Latim.
} 
prioridade, assim, a outros gêneros, como a épica e a lírica, ou ainda, no caso de Kury, ao gênero dramático grego (tragédia e comédia).

Um outro fato que merece destaque nesse período é a consolidação das universidades brasileiras e, por consequência disso, dos estudos científicos. Apesar de já haver, no Brasil, faculdades desde o séc. XIX, havendo já cursos como medicina, direito e engenharia, os primeiros centros universitários surgiram apenas das primeiras décadas do séc. XX. Podemos destacar a fundação da Universidade do Paraná (hoje UFPR), em 1912; da Universidade do Rio de Janeiro (hoje UFRJ), em 1920; da Universidade de São Paulo, em 1934; e da Universidade Federal do Distrito Federal, em 1935, além de outras, que se seguiram. ${ }^{14}$

Sobre as traduções plautinas produzidas nesse período, ao todo, até onde nossa investigação apurou, foram produzidas dezoito traduções ${ }^{15}$, um número relativamente pequeno se olharmos para outros gêneros da cultura clássica ${ }^{16}$; mas expressivo, se olharmos para a única tradução feita no século XIX, apresentada na seção anterior. Dentro dessas manifestações tradutórias, podemos salientar as traduções de alguns estudiosos importantes como Agostinho da Silva, Aída Costa, José Dejalma Dezotti e Jaime Bruna.

A partir dessas traduções, podemos fazer algumas considerações a respeito do repertório plautino traduzido nesse período: das vinte e uma comédias que chegaram até nós, apenas oito comédias individuais foram traduzidas: Amphitruo (Anfitrião), Aulularia (Aululária), Captivi (Os Cativos), Menaechmi (Os Menecmos), Bacchides (Báquides), Rudens (O Cabo), Miles Gloriosus (O Soldado Fanfarrão) e Curculio (Caruncho ou O Gorgulho).

Ainda sobre essa questão, ressaltamos o número de traduções que ocorreram dessas obras nesse período. Dentre elas, a peça mais traduzida foi a Aululária, tendo quatro traduções de diferentes estudiosos. Logo em seguida, destacamos, nessa lista, Os Menecmos que tiveram três traduções

\footnotetext{
${ }^{14}$ Cf. Duarte (2016, p. 54).

${ }^{15} \mathrm{Cf}$. mais à frente uma lista completa.

${ }^{16}$ Cf. Fernandes (2017, p. 106-112).
} 
diferentes nesse período, mostrando, assim, uma certa preferência tradutória, junto com a Aululária, por essas duas obras plautinas. ${ }^{17}$

Com duas traduções, destacamos as peças O Soldado Fanfarrão, Os Cativos (ou Os Prisioneiros), e O Gorgulho (Caruncho). Por último, tendo apenas uma tradução, aparecem as peças O Cabo e As Bacanas.

Para ressaltar o que acabamos de desenvolver, podemos observar a seguinte reflexão de Bruna (1978), que traduziu cinco peças plautinas:

\footnotetext{
Dessas [das vinte e uma comédias de Plauto que chegaram até nós], têm gozado merecida preferência Anfitrião, Aululária, Trinumo e as cinco comédias selecionadas para este volume [O Cabo, Caruncho, Os Menecmos, Os Prisioneiros, O Soldado Fanfarrão]. (BRUNA, 1978, p. 2)
}

Dentre os principais tradutores plautinos desse período, um grande nome que se destaca é o de Agostinho da Silva (1906-1994). Agostinho, nascido em terras lusitanas, foi poeta, tradutor e filósofo, tendo atuado intensamente no Brasil, na década de 1940. Apesar do tradutor ter origem lusitana, a proposta desse trabalho é analisar as traduções plautinas publicadas no idioma vernáculo no Brasil, e pertencentes, assim, a uma historiografia brasileira, independente da nacionalidade de seu tradutor.

Agostinho publica, pela Editora Globo, em 1952, quatro comédias de Plauto que, junto com duas de Terêncio, outro comediógrafo republicano, integram o volume Comédia Latina. Essas quatro comédias são Anfitrião, Aululária, Os Cativos e O Gorgulho. Primeiramente, é importante observar o grande empenho tradutório de Agostinho ao traduzir quatro comédias, das quais três ainda eram inéditas no Brasili18, e com isso, proporcionar uma expansão significante de traduções plautinas no sistema literário brasileiro.

Já sobre sua prática tradutória, Agostinho destaca as dificuldades de traduzir alguns elementos próprios do texto cômico, como jogos de palavras

\footnotetext{
17 Sobre as múltiplas traduções de Menecmos, isso se explicaria, mesmo que haja ainda necessidade de mais provas para afirmar isso, pela influência da obra de Shakespeare, A Comédia dos Erros (The Comedy of Errors), que é um famoso texto baseado na peça plautina.

${ }^{18}$ Até o momento em que foram publicadas essas quatro traduções de Agostinho, só havia, em território brasileiro, como vimos na seção anterior, a tradução da Aulularia (1888), realizada pelo Barão de Paranapiacaba. Com isso, Agostinho foi o segundo tradutor que se debruçou sobre as comédias plautinas no Brasil.
} 
e frases de duplo sentido, além de fatos e costumes pertencentes à época do texto de partida para uma língua moderna. Por fim, ele ressalta que sua tradução buscou ao máximo ser fiel ao texto original, conservando, tanto quanto possível, o registro da língua. Vejamos um pequeno trecho presente na sua "nota sobre tradução":

\begin{abstract}
A presente versão procurou seguir o mais possível o original e em caso nenhum se sacrificou a fidelidade à elegância de dição ou à fidelidade de inteligência; teve-se igualmente em mira conservar quanto possível o tom geral da linguagem, que era, como se sabe, não o latim literário de Cícero ou de César, nem o latim vulgar, que deu o acervo essencial das línguas românicas, mas, basicamente, o latim familiar ou coloquial de Roma, empregado na conversação das pessoas cultas (SILVA, 1952, p. 31 e 32)
\end{abstract}

Uma outra tradutora que merece destaque é Aída Costa, que foi catedrática de Literatura Latina da Universidade Federal de Minas Gerais, professora colaboradora de Língua e Literatura Latinas da Universidade de São Paulo e traduziu a comédia latina Aulularia, publicada em 1967. A partir dessa escolha, é interessante notar que os três primeiros tradutores plautinos no Brasil (Barão de Paranapiacaba, Agostinho da Silva, e agora Aída Costa) escolheram a obra Aulularia para traduzir, mostrando, assim, o lugar central que essa comédia possuía, nesses últimos anos, em relação às outras obras do mesmo poeta.

Por último, mas não menos importante, podemos destacar as traduções do professor de latim José Dejalma Dezotti, da Universidade Estadual Paulista (UNESP), para o grupo Giz-em-scène de leituras dramatizadas, também da UNESP, que foi fundado durante o segundo encontro da Sociedade Brasileira de Estudos Clássicos (SBEC), em $1985^{19}$. Como o principal objetivo desse grupo é realizar leituras dramatizadas, essas traduções possuem um foco diferente das traduções comentadas anteriormente: em vez de se apresentarem como uma tradução prosaica ou filológica, elas são realizadas com o interesse de serem encenadas ao público. É interessante destacar esse ponto, pois, no Brasil, é a primeira vez, até onde

\footnotetext{
${ }^{19}$ Para saber mais sobre o grupo Giz-en-scène, conferir Santos (2001)
} 
nossa pesquisa verificou, que as comédias de Plauto são traduzidas objetivamente para um fim performático. ${ }^{20}$

As comédias plautinas traduzidas por Dezotti et ali nesse final de século são três: Os Menecmos (1995), A comédia da marmita: Aulularia (1996) e O Soldado Fanfarrão (1999). Mais uma vez, observamos a escolha da peça Aulularia, dentre 21 comédias plautinas que chegaram até nós, para uma nova tradução, com uma nova proposta tradutória. Esse fato evidencia que essa peça, na década de 90, ainda estava no centro dos estudos tradutórios de Plauto no Brasil.

\section{Traduções plautinas do século XXI}

O século XXI foi muito produtivo para os estudos tradutórios de Plauto. Já com uma consolidação dos estudos clássicos nos anos anteriores, nas universidades brasileiras, outros pesquisadores puderam se dedicar a mais diversificados objetos da literatura latina, dentre eles o drama cômico. Além disso, os estudos da tradução também se expandiram em algumas universidades, e tiveram um papel fundamental em algumas das traduções que iremos apresentar nesta seção.

A primeira tradução realizada nos primeiros anos desse novo milênio foi o Estico, em 2006, da professora Isabella Tardin Cardoso, da Universidade Estadual de Campinas (Unicamp). Essa publicação merece um destaque especial porque, além de realizar um estudo filológico riquíssimo sobre a comédia latina, se coloca como uma tradução inédita no Brasil (e em língua portuguesa) de uma peça pouco canônica ${ }^{21}$.

Além dessa tradução, Cardoso orientou outros dois trabalhos de mestrado que geraram, como resultados finais, duas traduções de Plauto: Cásina (tradução inédita no Brasil), de Carol Rocha (2010), atualmente professora de latim da Universidade Federal de Juiz de Fora (UFJF), e o Anfitrião, de Lilian Almeida (2010), doutora em Linguística pela Universidade Estadual de Campinas (Unicamp). Esse movimento

\footnotetext{
${ }^{20}$ Aqui não estamos considerando montagens teatrais propriamente ditas, que efetivamente devem ter se valido de traduções já publicadas, ou partiram de traduções indiretas. Para ampliar a historiografia das traduções de Plauto, caberia uma pesquisa dedicada às montagens do texto plautino no teatro.

${ }^{21}$ A tradução foi finalista do 49ํㅜ Prêmio Jabuti, de 2007, na categoria de melhor tradução.
} 
universitário é expressivo para uma consolidação de um grupo de tradutores que estudam os textos plautinos no Brasil.

Destacamos o que ressaltam essas duas tradutoras acerca de um "método" de tradução das comédias plautinas:

\begin{abstract}
A tradução de um texto deveria contemplar não só a conversão de um idioma ao outro, mas também uma adaptação, dentro dos limites do possível, da linguagem poética presente no original. No caso do texto plautino, certas particularidades - como a presença de arcaísmos, coloquialismos e termos técnicos, além da abundância de efeitos sonoros e demais realizações - demandam uma tradução cautelosa, se o objetivo é recuperar recursos poéticos. (COSTA, 2013, p. 29)
\end{abstract}

Entre as dificuldades que se impõem durante o processo de tradução de um texto latino para o português, diversos aspectos tornam laboriosa a versão de uma comédia de Plauto. Em primeiro lugar, deparamo-nos com o latim arcaico. Além disso, lidamos com um texto dramático - e do gênero cômico - que é, muitas vezes, escrito em linguagem mais informal. Isso sem contar a métrica variada, cujos efeitos junto ao público plautino são apenas hoje minimamente inferíveis. E, como qualquer tradução, a maneira de lidar com tais diversidades derivará das escolhas do tradutor, que acabam por delinear a versão produzida. (ROCHA, 2013, p. 83)

É notório o interesse pela questão da variação linguística (seja no tempo, quando tratam da variação em função de um período arcaico de produção das peças, seja no espaço, quando pensam nos usos dos variados latins, ora coloquial ora técnico ora poético, etc.). O modus faciendi então dessas duas traduções remonta claramente à tradução de Cardoso (2006), que persegue os mesmos objetivos: ${ }^{22}$ tratar da questão da uarietas da linguagem e seus efeitos. O rigor filológico se coloca nessas traduções acima de qualquer outro objetivo, o que fica atestado nas próprias palavras de Cardoso: “[p]rocurei apontar alguns dos mais salientes [efeitos cômicos gerados pela variação linguística]: algumas vezes em meu modesto uertere, outras vezes em notas, sobretudo nos casos em que uma versão mais ‘literária' obscurecesse aspectos filológicos” (2006, p. 64).

${ }^{22}$ Cf. Cardoso (2006, p. 61-65). 
Ainda no ambiente acadêmico, em 2007, surge uma tradução de $O$ Mercador, de Damares Barbosa Correia.

Um outro movimento tradutório que merece reconhecimento é o dos professores de Letras Clássicas da Universidade Federal do Paraná (UFPR). A proposta desses professores é traduzir os versos de poetas gregos e latinos, dentre eles os versos de Plauto, com uma abordagem polimétrica, tentando recriar, assim, o caráter rítmico e performático que havia nesses textos, coincidindo sílabas breves e longas, do sistema métrico greco-romano, com sílabas tônicas e átonas, do sistema métrico português.

Leandro Cardoso, que pertence a esse grupo citado no parágrafo anterior, foi orientado pelo professor Rodrigo Tadeu Gonçalves, no programa de pós-graduação em Letras da UFPR, e realizou uma tradução do Anfitrião em versos (2012), proposta inédita no Brasil para essa peça. Sua tradução, como já mencionada acima, segue a proposta de recriação dos versos latinos para versos rítmicos e performativos adaptados para o sistema português. Nas palavras de Cardoso:

\begin{abstract}
A proposta de tradução aqui apresentada para a peça plautina é, conforme já dissemos, a de uma tradução poética. [...] A tradução acaba, assim, se revelando uma poética experimental, no sentido de que constrói uma poética para a poética que traduz de maneira a possibilitar a sua experiência ao mesmo tempo em que a demonstra. (2012, p. 11-21)
\end{abstract}

É interessante observar que, num intervalo de dois anos, tivemos duas traduções da comédia Anfitrião, com duas propostas tradutórias diferentes (uma em prosa e outra em verso), enriquecendo uma historiografia das traduções plautinas nesse começo de milênio.

A partir de 2011, a Imprensa da Universidade de Coimbra passa a publicar seus volumes da "Série Autores Gregos e Latinos" em conjunto com a Annablume Editora, da Universidade de São Paulo. Assim, consideramos aqui neste levantamento também as traduções publicadas pela IUC/Annablume a partir de 2011, que estão todas disponibilizadas gratuitamente pelo portal Classica Digitalia23, da Universidade de Coimbra.

${ }^{23}$ Acesso em: <https://classicadigitalia.uc.pt>. 
Então passamos a ter acesso a quatro novas traduções, incluindo de três peças ainda sem tradução anteriormente. Em 2011, O truculento (Truculentus), publicado no ano anterior somente pela IUC, resultado da dissertação de mestrado de Adriano Milho Cordeiro. Em 2014, A comédia do fantasma (Mostellaria), que é uma reedição da tradução de Reina Marisol Troca Pereira, de 2002; e ainda em 2014, da mesma tradutora, As três moedas (Trinummus). Em 2017, aparece O mercador (Mercator), do professor Aires Pereira do Couto.

\section{Levantamento das traduções brasileiras de Plauto}

Sistematizando, então, o que apresentamos nas seções anteriores, seguem as tabelas que elencam o título da peça em latim, sua tradução para o português, o nome do tradutor, o ano de publicação (apenas da primeira edição), e uma breve descrição do modo tradutório.

\begin{tabular}{|l|l|l|l|l|}
\hline \multicolumn{2}{|l|}{ Século XIX } \\
\hline Aulularia & A Marmita & $\begin{array}{l}\text { Barão de } \\
\text { Paranapiacaba }\end{array}$ & 1888 & $\begin{array}{l}\text { Sistema de versos } \\
\text { vernáculos }\end{array}$ \\
\hline
\end{tabular}

\begin{tabular}{|c|c|c|c|c|}
\hline \multicolumn{5}{|l|}{ Século XX } \\
\hline Amphitruo & Anfitrião & Agostinho da Silva & 1952 & Prosa \\
\hline Aulularia & Aululária & Agostinho da Silva & 1952 & Prosa \\
\hline Captiui & Os cativos & Agostinho da Silva & 1952 & Prosa \\
\hline Curculio & O gorgulho & Agostinho da Silva & 1952 & Prosa \\
\hline Aulularia & $\begin{array}{l}\text { Aululária: a } \\
\text { comédia da } \\
\text { panelinha }\end{array}$ & Aída Costa & 1967 & Prosa \\
\hline Menaechmi & $\begin{array}{l}\text { Os } \\
\text { Menecmos }\end{array}$ & $\begin{array}{l}\text { Diógenes de } \\
\text { Araújo Netto e } \\
\text { José Venâncio } \\
\text { Ferreira }\end{array}$ & 1975 & Prosa \\
\hline Bacchides & As Bacanas & Newton Belleza & 1977 & Prosa \\
\hline Rudens & O cabo & Jaime Bruna & 1978 & Prosa \\
\hline
\end{tabular}




\begin{tabular}{|c|c|c|c|c|}
\hline Curculio & Carunho & Jaime Bruna & 1978 & Prosa \\
\hline Menaechmi & $\begin{array}{l}\text { Os } \\
\text { Menecmos }\end{array}$ & Jaime Bruna & 1978 & Prosa \\
\hline Captiui & $\begin{array}{l}\text { Os } \\
\text { prisioneiros }\end{array}$ & Jaime Bruna & 1978 & Prosa \\
\hline $\begin{array}{l}\text { Miles } \\
\text { Gloriosus }\end{array}$ & $\begin{array}{l}\text { O soldado } \\
\text { fanfarrão }\end{array}$ & Jaime Bruna & 1978 & Prosa \\
\hline Amphitruo & Anfitrião & Otávio T. de Brito & 1981 & Prosa \\
\hline Aulularia & $\begin{array}{l}\text { A comédia da } \\
\text { marmita }\end{array}$ & $\begin{array}{l}\text { Walter de } \\
\text { Medeiros }\end{array}$ & 1994 & Prosa \\
\hline Menaechmi & $\begin{array}{l}\text { Os } \\
\text { Menecmos }\end{array}$ & $\begin{array}{l}\text { José Dejalma } \\
\text { Dezotti }\end{array}$ & 1995 & $\begin{array}{l}\text { Prosa } \\
\text { (Adaptação para } \\
\text { leitura dramática) }\end{array}$ \\
\hline Aulularia & $\begin{array}{l}\text { A comédia da } \\
\text { marmita }\end{array}$ & $\begin{array}{l}\text { José Dejalma } \\
\text { Dezotti }\end{array}$ & 1996 & $\begin{array}{l}\text { Prosa } \\
\text { (Adaptação para } \\
\text { leitura dramática) }\end{array}$ \\
\hline $\begin{array}{l}\text { Miles } \\
\text { Gloriosus }\end{array}$ & $\begin{array}{l}\text { O soldado } \\
\text { fanfarrão }\end{array}$ & $\begin{array}{l}\text { José Dejalma } \\
\text { Dezotti }\end{array}$ & 1999 & $\begin{array}{l}\text { Prosa } \\
\text { (Adaptação para } \\
\text { leitura dramática) }\end{array}$ \\
\hline
\end{tabular}

\begin{tabular}{|c|c|c|c|c|}
\hline \multicolumn{5}{|l|}{ Século XXI } \\
\hline Stichus & Estico & $\begin{array}{l}\text { Isabella Tardin } \\
\text { Cardoso }\end{array}$ & 2006 & Prosa \\
\hline Mercator & O Mercador & $\begin{array}{l}\text { Damares Barbosa } \\
\text { Correia }\end{array}$ & 2007 & $\begin{array}{l}\text { Prosa } \\
\text { (Dissertação) }\end{array}$ \\
\hline Truculentus & O truculento & $\begin{array}{l}\text { Adriano Milho } \\
\text { Cordeiro }\end{array}$ & 2011 & $\begin{array}{l}\text { Prosa } \\
\text { (Dissertação) }\end{array}$ \\
\hline Amphitruo & Anfitrião & Leandro Cardoso & 2012 & $\begin{array}{l}\text { Versos rítmicos } \\
\text { (Dissertação) }\end{array}$ \\
\hline Amphitruo & Anfitrião & $\begin{array}{l}\text { Lilian Nunes da } \\
\text { Costa }\end{array}$ & 2013 & $\begin{array}{l}\text { Prosa } \\
\text { (Dissertação) }\end{array}$ \\
\hline Casina & Cásina & Carol Rocha & 2013 & $\begin{array}{l}\text { Prosa } \\
\text { (Dissertação) }\end{array}$ \\
\hline
\end{tabular}




\begin{tabular}{|l|l|l|l|l|}
\hline Trinummus & $\begin{array}{l}\text { As três } \\
\text { moedas }\end{array}$ & $\begin{array}{l}\text { Reina Marisol } \\
\text { Troca Pereira }\end{array}$ & 2014 & Prosa \\
\hline Mostellaria & $\begin{array}{l}\text { A comédia } \\
\text { do fantasma }\end{array}$ & $\begin{array}{l}\text { Reina Marisol } \\
\text { Troca Pereira }\end{array}$ & 2014 & Prosa \\
\hline Mercator & O mercador & $\begin{array}{l}\text { Aires Pereira do } \\
\text { Couto }\end{array}$ & 2017 & Prosa \\
\hline
\end{tabular}

\section{LISTA DE TRADUÇÕES POR PEÇA}

\begin{tabular}{|c|c|c|c|}
\hline \multirow[t]{4}{*}{ Amphitruo } & Agostinho da Silva & 1952 & Prosa \\
\hline & Otávio T. de Brito & 1981 & Prosa \\
\hline & Lilian Nunes da Costa & 2013 & Prosa \\
\hline & Leandro Cardoso & 2012 & $\begin{array}{l}\text { Versos rítmicos } \\
\text { (Dissertação) }\end{array}$ \\
\hline \multirow[t]{5}{*}{ Aulularia } & Barão de Paranapiacaba & 1888 & $\begin{array}{l}\text { Sistema de versos } \\
\text { vernáculos }\end{array}$ \\
\hline & Agostinho da Silva & 1952 & Prosa \\
\hline & Aída Costa & 1967 & Prosa \\
\hline & Walter de Medeiros & 1994 & Prosa \\
\hline & José Dejalma Dezotti & 1996 & $\begin{array}{l}\text { Prosa } \\
\text { (Adaptação para leitura } \\
\text { dramática) }\end{array}$ \\
\hline Bacchides & Newton Belleza & 1977 & Prosa \\
\hline \multirow[t]{2}{*}{ Captiui } & Agostinho da Silva & 1952 & Prosa \\
\hline & Jaime Bruna & 1978 & Prosa \\
\hline Casina & Carol Rocha & 2013 & Prosa \\
\hline \multirow[t]{2}{*}{ Curculio } & Agostinho da Silva & 1952 & Prosa \\
\hline & Jaime Bruna & 1978 & Prosa \\
\hline \multirow[t]{2}{*}{ Menaechmi } & $\begin{array}{l}\text { Diógenes de Araújo } \\
\text { Netto e José Venâncio } \\
\text { Ferreira }\end{array}$ & 1975 & Prosa \\
\hline & Jaime Bruna & 1978 & Prosa \\
\hline
\end{tabular}




\begin{tabular}{|l|l|l|l|}
\hline \multirow{2}{*}{ Mercator } & José Dejalma Dezotti & 1995 & $\begin{array}{l}\text { Prosa } \\
\text { (Adaptação para leitura } \\
\text { dramática) }\end{array}$ \\
\hline \multirow{2}{*}{$\begin{array}{l}\text { Miles } \\
\text { Gloriosus }\end{array}$} & $\begin{array}{l}\text { Damares Barbosa } \\
\text { Correia }\end{array}$ & 2007 & $\begin{array}{l}\text { Prosa } \\
\text { (Dissertação) }\end{array}$ \\
\cline { 2 - 4 } & Aires Pereira do Couto & 2017 & Prosa \\
\cline { 2 - 4 } & Jaime Bruna Dejalma Dezotti & 1999 & $\begin{array}{l}\text { Prosa } \\
\text { (Adaptação para leitura } \\
\text { dramática) }\end{array}$ \\
\hline Mostellaria & Reina Marisol Troca & 2014 & Prosa \\
\hline Rudens & Jereira & 1978 & Prosa \\
\hline Stichus & Isabella Tardin Cardoso & 2006 & Prosa \\
\hline Trinummus & Reina Marisol Troca & 2014 & Prosa \\
\hline Truculentus & Pereira & 2011 & Prosa \\
\hline
\end{tabular}

\section{À guisa de conclusão}

Por fim, vale notar que, no Brasil, apenas 13 obras de Plauto contam com traduções, ou seja, há muito ainda a ser feito. Se uma história das traduções está sendo escrita, como dissemos, essa história está sendo escrita ao mesmo tempo em que as traduções estão sendo feitas. E, ao analisar esse caminho das traduções, percebemos que a estrada à frente é francamente extensa ainda.

À guisa de conclusão, poderíamos dizer que, mesmo que de forma pouco central e não predominante, Plauto ainda se mantém no horizonte de interesse dos tradudores e pesquisadores.

Outras traduções estão em desenvolvimento e devem ser lançadas futuramente. Destacamos a tradução do Persa, do professor Beethoven Alvarez, da Universidade Federal Fluminense (UFF), que está em fase de revisão para futura publicação. $O$ professor encontra-se atualmente traduzindo o Poenulus, cujos resultados já podem ser vistos preliminarmente 
em Alvarez (2019). Além disso, como futuro resultado de sua dissertação de mestrado, Renan Rodriguez prepara a tradução da Asinaria. Em Curitiba, temos notícia que o Pseudolus vem sendo traduzido pelo professor Rodrigo Gonçalves e um grupo de estudantes da Universidade Federal do Paraná.

Seria muito alvissareiro um efetivo esforço editorial que reunisse um grupo de tradutores e propussesse a tradução integral de Plauto numa única coleção, aos moldes do que vem tentando realizar a Imprensa Nacional Casa de Moeda, de Portugal. Assim, leitores e estudantes teriam acesso completo, finalmente, às fundamentais e divertidíssimas comédias plautinas. Uma nova página nessa história seria escrita.

Anexo: lista de traduções por peça incluindo publicações portuguesas

\begin{tabular}{|c|c|c|c|c|}
\hline \multirow[t]{5}{*}{ Amphitruo } & Agostinho da Silva & 1952 & br & Prosa \\
\hline & $\begin{array}{l}\text { Carlos Alberto L } \\
\text { Fonseca }\end{array}$ & 1978 & $\mathrm{pt}$ & Prosa \\
\hline & Otávio T. de Brito & 1981 & br & Não tive acesso \\
\hline & Lilian Nunes da Costa & 2013 & br & Prosa \\
\hline & Leandro Cardoso & 2012 & br & Versos rítmicos (diss.) \\
\hline Asinaria & Aires Pereira do Couto & 2003 & $\mathrm{pt}$ & Prosa \\
\hline \multirow[t]{5}{*}{ Aulularia } & Barão de Paranapiacaba & 1888 & br & $\begin{array}{l}\text { Sistema de versos } \\
\text { vernáculos }\end{array}$ \\
\hline & Agostinho da Silva & 1952 & br & Prosa \\
\hline & Aída Costa & 1967 & br & Prosa \\
\hline & Walter de Medeiros & 1985 & pt & Prosa \\
\hline & José Dejalma Dezotti & 1996 & br & Prosa (p/ leit. dramat.) \\
\hline \multirow[t]{2}{*}{ Bacchides } & Newton Belleza & 1977 & br & Prosa \\
\hline & Claudia Teixeira & 2006 & $\mathrm{pt}$ & Prosa \\
\hline \multirow[t]{3}{*}{ Captiui } & Agostinho da Silva & 1952 & br & Prosa \\
\hline & Jaime Bruna & 1978 & br & Prosa \\
\hline & Helena Costa Toipa & 2006 & $\mathrm{pt}$ & Prosa \\
\hline Casina & Aires Pereira do Couto & 2006 & pt & Prosa \\
\hline
\end{tabular}




\begin{tabular}{|c|c|c|c|c|}
\hline & Carol Rocha & 2013 & br & Prosa \\
\hline Cistellaria & Aires Pereira do Couto & 2004 & $\mathrm{pt}$ & Prosa (FESTEA) \\
\hline \multirow[t]{3}{*}{ Curculio } & Agostinho da Silva & 1952 & br & Prosa \\
\hline & $\begin{array}{l}\text { Walter de Sousa } \\
\text { Medeiros }\end{array}$ & 1978 & $\mathrm{pt}$ & Prosa \\
\hline & Jaime Bruna & 1978 & br & Prosa \\
\hline Epidicus & $\begin{array}{l}\text { Walter de Sousa } \\
\text { Medeiros }\end{array}$ & 1980 & $\mathrm{pt}$ & Prosa \\
\hline \multirow[t]{4}{*}{ Menaechmi } & $\begin{array}{l}\text { Diógenes de Araújo } \\
\text { Netto e José Venâncio } \\
\text { Ferreira }\end{array}$ & 1975 & br & Não tive acesso \\
\hline & Jaime Bruna & 1978 & br & Prosa \\
\hline & $\begin{array}{l}\text { Carlos Alberto L } \\
\text { Fonseca }\end{array}$ & 1983 & $\mathrm{pt}$ & Prosa \\
\hline & José Dejalma Dezotti & 1995 & br & Prosa (p/ leit. dramat.) \\
\hline \multirow[t]{2}{*}{ Mercator } & $\begin{array}{l}\text { Damares Barbosa } \\
\text { Correia }\end{array}$ & 2007 & br & Prosa (diss.) \\
\hline & Aires Pereira do Couto & 2017 & $\mathrm{pt} / \mathrm{br}$ & Prosa \\
\hline \multirow[t]{4}{*}{$\begin{array}{l}\text { Miles } \\
\text { Gloriosus }\end{array}$} & $\begin{array}{l}\text { Carlos Alberto L } \\
\text { Fonseca }\end{array}$ & 1968 & $\mathrm{pt}$ & Prosa \\
\hline & Jaime Bruna & 1978 & br & Prosa \\
\hline & José Dejalma Dezotti & 1999 & br & Prosa (p/ leit. dramat.) \\
\hline & $?$ & 1999 & $\mathrm{pt}$ & Ed. colibri \\
\hline Mostellaria & $\begin{array}{l}\text { Reina Marisol Troca } \\
\text { Pereira }\end{array}$ & 2014 & $\mathrm{pt} / \mathrm{br}$ & Prosa \\
\hline Persa & $\begin{array}{l}\text { Maria Isabel R } \\
\text { Gonçalves }\end{array}$ & 1999 & $\mathrm{pt}$ & Prosa \\
\hline Poenulus & José Luís Brandão & 2009 & $\mathrm{pt}$ & Prosa (FESTEA) \\
\hline Rudens & Jaime Bruna & 1978 & br & Prosa \\
\hline Stichus & Isabella Tardin Cardoso & 2006 & br & Prosa \\
\hline Trinummus & $\begin{array}{l}\text { Reina Marisol Troca } \\
\text { Pereira }\end{array}$ & 2014 & $\mathrm{pt} / \mathrm{br}$ & Prosa \\
\hline
\end{tabular}




\begin{tabular}{|l|l|l|l|l|}
\hline Truculentus & $\begin{array}{l}\text { Adriano Milho } \\
\text { Cordeiro }\end{array}$ & 2010 & $\mathrm{pt} / \mathrm{br}$ & Prosa \\
\hline Vidularia & & & & \\
\hline
\end{tabular}

\section{Referências}

ALVAREZ, B. B. Traduzindo Plauto em verso: o prólogo de Poenulus. In:

PAGANINE, C.; HANNES, V. Tradução e Criação: Entrelançamentos. Campinas: Pontes, 2019.

AMPARO, F. V. da S. do. Sob o véu dos versos: o lugar da poesia na obra de Machado de Assis. Rio de Janeiro, 2008. Tese (Doutorado) - Universidade Federal do Rio de Janeiro, 2008.

CAIROLLI, F.P. Marcial brasileiro. 2014. Dissertação (Mestrado em Letras Clássicas) - Faculdade de Filosofia, Letras e Ciências Humanas, Universidade de São Paulo, São Paulo, 2014. Disponível em: http://www.teses.usp.br/teses/disponiveis/8/8143/tde-23012015-183016/ptbr.php Acesso em: 08 mar. 2019.

CARDOSO, L. D. A Vez do Verso: Estudo e Tradução do Amphitruo, de Plauto. Dissertação (Mestrado em Letras) - Programa de Pós-Graduação em Letras, UFPR. Paraná, 2012. Disponível em: https://www.academia.edu/2458505/A_vez_do_verso_estudo_e_tradu\%C3 \%A7\%C3\%A3o_do_Amphitruo_de_Plauto. Acesso em 08 mar. 2019.

DAROS, R. P. Dom Pedro II: o imperador tradutor. Scientia traductionis, $n$. 11, p. 227- 244, 2012. Disponível em https://periodicos.ufsc.br/index.php/scientia/article/ viewFile/19804237.2012n11p227/22658. Acesso em 29 fev. 2019

DUARTE, A.S. Por uma história da tradução dos clássicos grego-latinos no Brasil. Translatio, n. 12, p. 43-62, 2016. Disponível em: https://seer.ufrgs.br/translatio/article/viewFile/69211/39854. Acesso em: 08 mar. 2019.

FERNANDES, T. A Literatura Latina no Brasil: uma história de traduções. 2017. Tese (Doutorado em Estudos da Tradução) - Programa de PósGraduação em Estudos da Tradução, Universidade Federal de Santa Catarina, Florianópolis, 2017. Disponível em 
https://repositorio.ufsc.br/bitstream/handle/123456789/187085/PGET0349T. pdf? sequence=-1\&isAllowed=y. Acesso em 08 mar. 2019.

FURLAN, M. (Org.). Dossiê: Em torno da (re-)tradução dos clássicos. In Scientia traductionis, n. 13, p. 281-348, 2013. Disponível em: https://periodicos.ufsc.br/index.php/scientia/article/view/30275. Acesso em 08 mar. 2019

GONÇALVES, R. T.; VIEIRA, B. V. G. (Orgs.). Dossiê: Tradução dos clássicos em português. Revista Letras, n. 89, p. 101-269, 2014. Disponível em: http://ojs.c3sl.ufpr.br/ojs2/index.php/letras/issue/view/1708. Acesso em 08 mar. 2019.

GONÇALVES, R.T.; FLORES, G.G. Polimetria Latina em Português. Revista

Letras, n. 89, p. 147-172, 2014. Disponível em https://revistas.ufpr.br/letras/article/view/35146. Acesso em 08 mar. 2019 PLAUTO. Aulularia (A marmita). Comédia em cinco atos de Marco Accio Plauto traduzida em versos portugueses pelo Barão de Paranapiacaba. Rio de Janeiro: Typographia Chrysalida, 1888. Disponível em https://digital.bbm.usp.br/handle/bbm/7591. Acesso em 08 mar. 2019.

PLAUTO. Comédias (O Cabo, Caruncho, Os Menecmos, Os Prisioneiros, O Soldado Fanfarrão). Tradução de Jaime Bruna. São Paulo: Editora Cultrix, 1978.

PLAUTO. Estico. Trad. Isabella Tardin Cardoso. Campinas: Editora Unicamp, 2006.

PLAUTO. O truculento. Trad. Adriano Milho Cordeiro. São Paulo: Annablume, 2011. (Autores gregos e latinos).

PLAUTO. Anfitrião. Introdução, tradução e notas de Lilian Nunes da Costa. Campinas: Mercado de Letras, 2013. (Coleção Aurora)

PLAUTO. Cásina. Trad. Carol Martins da Rocha. Campinas: Mercado de Letras, 2013. (Coleção Aurora)

PLAUTO; TERÊNCIO. A comédia latina (Anfitrião, Aululária, Os cativos, O gorgulho, Os adelfos, O eunuco). Prefácio, escolha, tradução e notas de Agostinho da Silva. Rio de Janeiro, Porto Alegre, São Paulo: Editora Globo, 1952.

REIS, D. da S. Impactos da Tradução escrita no Brasil do século XIX. Tradução em Revista, n. 18. Rio de Janeiro: PUC-RIO, 2015. Disponível em: 
https://www.academia.edu/14133981/Impactos_da_tradu\%C3\%A7\%C3\%A 3o_escrita_no_s\%C3\%A9culo_XIX. Acesso em 08 mar. 2019.

SANTOS, Fernando Brandão dos. Grupo Giz-en-Scène de leituras dramatizadas de textos clássicos. Universidade Estadual Paulista (UNESP), 2001. Disponível em: http://hdl.handle.net/11449/148143. Acesso em 09 mar. 2019.

TUFFANI, E. Repertório Brasileiro de Língua e Literatura Latina, 18301996. Cotia: Íbis, 2006.

VASCONCELLOS, P. S. de. A tradução poética e os Estudos Clássicos no Brasil de hoje: algumas considerações. Scientia traductionis, n. 7, p. 68-79, 2011.

VIEIRA, B. V. G. Um tradutor de latim sob D. Pedro II: perspectivas para a história da tradução literária greco-romana em português. Revista Letras, n. 80, p. 71-87, 2010. Disponível em http://ojs.c3sl.ufpr.br/ojs2/index.php/letras/article/view/17072. Acesso em 02 mar. 2019.

\section{Resumo}

Neste artigo, apresentamos um estudo sobre a historiografia das traduções produzidas ou publicadas no Brasil, desde o século XIX até hoje, 2019, da obra de Tito Mácio Plauto (c. 254-184 a.C.). Este texto pretende investigar o percurso tradutório das comédias de Plauto no Brasil, elucidando neste caminho, de forma ainda que breve, o contexto das traduções e um pouco de seus processos e projetos, contribuindo com uma história da tradução da literatura latina no Brasil. Pretendemos sistematizar aqui uma história apenas das traduções plautinas já produzidas e publicadas no Brasil, destacando os principais nomes que atuaram nessa produção. Para isso, dividimos esse artigo em três recortes diacrônicos, cada um relativo a um século (XIX, XX e XXI), refletindo três momentos distintos da produção tradutória no Brasil. Esse estudo, embora tenha também um caráter um tanto quantitativo, como os próprios trabalhos de Fernandes (2017), Duarte (2016) e Tuffani (2006), pretende ir um pouco além, propondo algumas reflexões 
sobre o estabelecimento de uma tradição tradutória no Brasil, a partir da análise de algumas discussões dos próprios tradutores de Plauto.

Palavras-chave: Comédia latina; Plauto, Historiagrafia da tradução.

\begin{abstract}
In this paper, we present a study on the historiography of the translations produced or published in Brazil, from the nineteenth century until today, of Plautus's plays (c. 254-184 BC). This text intends to investigate the translation trajectory of Plautus' comedies in Brazil, elucidating, although briefly, the context of translations and some of their processes and projects, contributing to a history of the translation of Latin literature in Brazil. We intend to systematize here a history only of the Plautine translations produced and published in Brazil, highlighting the main names that acted in this production. For this, we divided this article into three diachronic sections, each related to a century (19th, 20th and 21st), reflecting three distinct moments of translation production in Brazil. This study, although also having a somewhat quantitative character, as the works of Fernandes (2017), Duarte (2016) and Tuffani (2006), intends to go a little further, proposing some reflections on the establishment of a translation tradition in Brazil and doing an analysis of some discussions that the Plautus translators themseleves undertake.
\end{abstract}

Keywords: Roman comedy; Plautus; Historiography of translation. 